\title{
ECOSYSTEM SERVICES IN THE MID-HILL FOREST OF WESTERN NEPAL: A CASE OF PANCHASE PROTECTED FOREST
}

\author{
Ananta Ram Bhandari, Udhab Raj Khadka*, Keshav Raj Kanel \\ Central Department of Environmental Science, Tribhuvan University, Kathmandu, Nepal \\ *Corresponding author: ukhadka@cdes.edu.np
}

(Received: July 11, 2018; Revised: September 27, 2018; Accepted: October 1, 2018)

\begin{abstract}
This paper identified ecosystem services of Panchase Protected Forest (PPF) in the mid-hills of western Nepal using the Economics of Ecosystem and Biodiversity (TEEB) framework. Transect walk, focus group discussion, key informants interview and expert's consultation were used. This study revealed that PPF offered wide range of ecosystem services including provisioning, regulating habitat, and cultural and amenity services. Provisioning services offered by PPF included food (35 species), raw materials ( 22 species), energy ( 17 species), medicines (40 species), ornamental resources (3 species) and water resources. The forest was also a source of water for irrigation and domestic consumption. The regulating services offered by PPF included water flow regulation, erosion prevention, water purification, soil fertility maintenance, air quality regulation and climate regulation. PPF provided habitat for 589 species of flowering plants, 24 species of mammals and 262 species of birds maintaining life cycles and genetic diversity. By maintaining landscape integrity and heritages, PPF provided opportunities for recreation and tourism. A total of 3,600 tourists and 25,340 pilgrims visit PPF every year. The beneficiary of ecosystem services from PPF ranged from local level to sub-national, national and global levels.
\end{abstract}

Keywords: Beneficiaries of forest, Cultural services, Habitat services, Provisioning services, Regulating services

\section{INTRODUCTION}

Ecosystem has both structural and functional components, and through continuous interaction of these components, ecosystems deliver crucial services to its functioning and to human society. Natural ecosystems provide a wide range of services and economic benefits to local livelihoods (Pant et al. 2012) and human wellbeing (MEA 2005). Millennium Ecosystem Assessment (MEA) defines ecosystem services as 'the benefits people obtain from ecosystems'. These benefits are the multiple commodities that are supplied by natural ecosystems as a result of their structure and function; the conditions and processes through which nature 'sustains human life' on earth (Daily 1997). Ecosystem services are ultimately the planet's life support systems we cannot live without (Cavelier et al. 2012).

MEA (2005) classifies ecosystem services into four broad categories viz. provisioning, regulating, cultural and supporting services. The Economics of Ecosystem and Biodiversity (TEEB 2010) classifies ecosystem services into four broad categories including provisioning, regulating, habitat, and cultural and amenity services. Provisioning and regulating services are similar in both TEEB and MEA classifications. However, supporting services of MEA classification is mostly included into the regulating services of TEEB classification. Cultural services of MEA classification are elaborated as 'cultural and amenity' services in TEEB classification. A new service type 'habitat services' is included in the TEEB classifications.
Despite small in size, Nepal is rich in natural resources and biodiversity that includes 118 ecosystems (Dobremez 1976) and 35 forest types (Stainton 1972). These forest types have been aggregated and categorized into 10 major groups namely, tropical forests, subtropical broadleaf forests, subtropical conifer forests, lower-temperate broadleaf forests, lower-temperate mixed broadleaf forests, upper-temperate broadleaf forests, uppertemperate mixed broadleaf forests, temperate conifer forests, subalpine forests, and alpine scrubs (GoN/MoFSC 2014). Forests cover $44.74 \%$ (6.61 million hectare) of the total area of the country (DFRS 2015). Forest Act (second amendment), 2016 classifies forests into two major categories, i.e. national forests and private forests. National forests are further classified into government managed forests, block forests, protected forests, collaborative forests, community forests, leasehold forests and religious forests (GoN 2016).

In order to better conserve these forests, Nepal has established 20 protected areas covering $23.3 \%$ of the total land area of the country. These protected areas represent 80 ecosystems out of 118 natural ecosystems of the country (GoN/MoFSC 2014). Emphasizing the importance of biodiversity and ecosystem services outside protected areas, Government of Nepal initiated 'protected forest' in 2012. Protected Forest is a special category of forest balancing human needs through conserving biodiversity, regulating ecosystem services and safeguarding environment (Shrestha et al. 2014). Panchase Protected Forest (PPF) was declared as a 
protected forest in 2012 (DoF 2012a). Till date, eight protected forests have been declared in Nepal covering $133,754.8$ hectares of forests (GoN/MoFSC 2014).

Although forests provide various goods and services for human wellbeing, the importance of ecosystem services arising from forests is not properly recognized in Nepal. Few ecosystem service studies have been conducted in Nepal's protected areas such as Koshi Tappu Wildlife Reserve (Sharma et al. 2015) and Shivapuri-Nagarjun National Park (Peh et al. 2016) and wetland sites such as Phewa Lake (CSUWN 2011), Beeshajari Lake (Khanal et al. 2014) and Jagadishpur Reservoir (Baral et al. 2016). However, no comprehensive study on ecosystem services of 'protected forest' is available. Even in Panchase Protected Forest, such information seems lacking. Therefore, the present research was carried out with the aim of identifying ecosystem services offered by Panchase Protected Forest and the beneficiaries of those services.

\section{MATERIALS AND METHODS}

\section{Study area}

The Panchase Protected Forest (PPF), lying at the juncture of Kaski, Syanja and Parbat districts in the western Nepal, comprises an area of 5,775.73 hectares (Fig. 1). It represents forests ecosystems of the mid-hills of Nepal. The forest is rich in biodiversity, as it has wide range of altitudinal variation from $900 \mathrm{~m}$ to $2517 \mathrm{~m}$. Out of total 35 forest types found in Nepal, PPF represents five forest types - alder forests, chirpine-broadleaved forest, oaklaurel forest, lower temperate oak forest, and SchimaCastanopsis forest (DoF 2012b). The PPF is dominated by Schima-Castanopsis forests, covering $69.89 \%$ (4036.39 ha) of the total area, which is one of the representative forest types of the mid-hills of Nepal. Chirpine-broadleaved forest covers $12.11 \%$ (699.25 ha), east Himalayan oak-laurel forest covers $11.14 \%(643.58$ ha), the lower temperate oak forest covers $5.86 \%$ (338.27 ha) and alder forest covers $1.01 \%$ (58.24 ha) of the forest area (DoF 2012b).

The PPF has been zoned as the core area and the fringe area. The core area includes 2,035 ha as the innermost area and fringe area includes 3740 ha of outer area. An impact zone has been declared around the PPF that covers the settlements within nine former VDCs (Village Development Committees) - three VDCs from each Kaski, Parbat and Syangja districts.

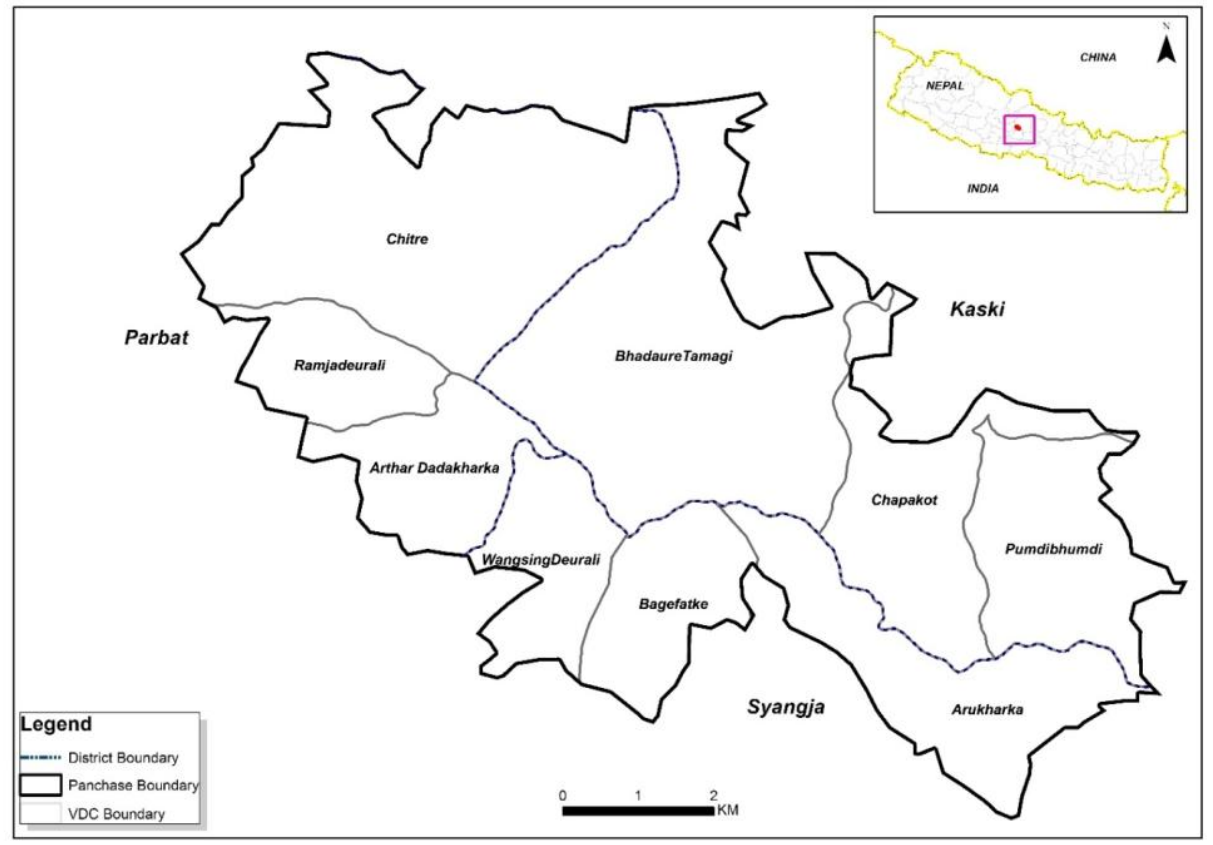

Fig. 1: Panchase Protected Forest and associated VDCs and districts

\section{Methods}

This study relied on both primary and secondary data. Transect walk, focus group discussion, key informants interview and expert's consultation was made to collect primary data whereas relevant literatures were reviewed to collect secondary data. A transect walk was made across the PPF in participation with local key informants in March 2015. A transect walk was a tool for describing and showing the location and distribution of resources, features, landscape, major land used along a given transect. Observation was made along transect to explore and identify ecosystem services of that particular forest. A checklist was used to capture information during field observation during the transect walk.

Focus Group Discussion (FGD) was employed to gather information on ecosystem services particularly 
availability, use pattern and beneficiaries of provisioning, and cultural and amenity services. FGD is a useful technique to gather data when the researcher is interested to exhume more deeply into an interest area (Baker 1999). Total three FGDs were conducted in three VDCs, one VDC from each district, using checklist. Among the VDCs, Bhadaure-Tamagi from Kaski district, Chitre from Parbat district and Bangephadke from Syangja district were selected for this purpose. A total of 39 local community members $(n=39)$ participated in the FGDs. Key Informants Interview (KII) was employed to identify ecosystem services offered by the forests, cultural and religious sites and events, natural heritages, and the beneficiaries of the services. It was also used to triangulate the information collected during field observation along transect. PPF council members, community forest user group members, hoteliers, and experts were selected as key informants. A total of 10 key informants $(n=10)$ were interviewed during the study. Experts were consulted particularly for regulating services and habitat services.

The beneficiaries of the ecosystem services were categorized as local, sub-national, national and global. Local beneficiaries included people from the impact zone of the protected forest. The VDCs within the impact zone of PPF include Pumdibhumdi, Chapakot, BhadaureTamagi of Kaski district; Chitre, Ramjhadeurali and Arther-Dandakharka of Parbat district; and Wansingdeurali, Bangephadke and Arukharka of Syangja district. Sub-national level beneficiaries include people from other VDCs of Syangja, Parbat and Kaski districts and downstream city areas such as Pokhara, Kusma, Baglung and Putalibazar. National level beneficiaries are the stakeholders beyond sub-national level beneficiaries within Nepal. Global level beneficiaries include the people from elsewhere outside Nepal.

\section{RESULTS AND DISCUSSION}

\section{Ecosystem services}

Ecosystem services available in the PPF were discussed under the categories of provisioning, regulating; habitat, and cultural and amenity services following the TEEB framework (TEEB 2010) which is primarily based on the MEA.

\section{Provisioning services}

Food, medicines, raw materials, energy sources, ornamental resources and water are provisioning services provided by PPF. The food products used by local people from PPF included leaves, shoots, fruits and seeds of plants. A total of 35 plant species have been found to be used as food in Panchase region (Table 1). The major plant species used as food include Juglans regia, Myrica esculenta, Rubus ellipticus, Berberis aristata, Emblica officinalis, Morus alba, Castanopsis indica, Dioscorea deltoidea, Ficus semicordata, Bauhinia variegata, Urtica dioica, Aesandra butyracea and Choerospondias axillaris. Bamboo shoots and mushrooms were also commonly used as food by local people in this area. PPF was rich in wild foods, but there seems to be no specific information available in terms of yields, distribution and seasonality of the products (GoN/DoF/UNDP 2014).

Panchase Protected Forest has been observed as a good source of medicinal herbs. A total of 40 medicinal plants from PPF were found to be traditionally used for medicine (Table 1). The major plant species used in the medicines were Justicia adhatoda, Emblica officinalis, Swertia chirayita, Rubia manjith, Berberis aristata, Acorus calamus, Aloe vera, Artimisia indica, Asparagus racemosus, Paris polyphylla, Terminalia bellirica, Terminalia chebula and Zanthoxylum armatum. Medicinal plants such as Swertia chirayita, Paris polyphylla and Asparagus racemosus were more important in this area due to their high market value (Chikanbanjar, 2015). However, detailed data on the status and consumption of the medicinal plants was lacking.

This assessment has found that timber was one of the prominent raw materials extracted by local people from PPF. A total of 16 species of plants have been used as timber. The tree species commonly used as timber are Schima wallichi, Castanopsis indica, Alnus nepalensis, Pinus roxburghii, Pinus wallichiana, Abies spectabilis, Daphniphyllum himalense, Quercus semicarpifolia, Quercus lamellosa, Quercus glauca, Rhododendron arboreum, Juglans regia, and Shorea robusta (Table1). Similarly, Arundinaria species, Bambusa nepalensis and Dendrocalamus strictus were widely used as construction materials as well as for making baskets and handicrafts. Daphne bholuwa and Edgeworthia gardneri were also available in this region, which were used for preparing Nepali handmade paper. Construction materials such as sand, gravel and stones were also extracted from the river streams within PPF mostly for local use. If a set of environment friendly guidelines are developed, the upstream of Pame can be a potential area for mining sands and gravels brought by the monsoon rains, which will also contribute in reducing siltation in Phewa Lake (Kanel 2015, GoN/DoF/UNDP 2014).

Fuel-wood was the major source of energy used for cooking and heating in this region. Left over biomass from tree species were used as fuel-wood. A total of 17 tree species from PPF were found to be used as fuel-wood (Table 1). The major fuel-wood species of PPF included Schima wallichi, Castanopsis indica, Alnus nepalensis, Daphniphyllum himalense, Rhododendron arboreum, Engelhardia aspicata, Lyonia ovalifolia, Symplocos racemosa, Eurya cerasifolia. High consumption of these species is due to their high burning efficiency. Although, it is in decreasing trend, charcoal was found to be used by 
occupational castes for local use in this region. The species mainly used to produce charcoal include Schima wallichii and Castanopsis indica. However, all species used for fuel-wood and timber seemed to be used in making charcoal.

\section{Table 1. Provisioning services provided by Panchase Protected Forest}

\begin{tabular}{|c|c|}
\hline Services & Name of the species used \\
\hline Food & $\begin{array}{l}\text { Juglans regia, Myrica esculenta, Rubus ellipticus, Berberis aristata, Emblica officinalis, } \\
\text { Morus alba, Castanopsis indica, Dioscorea bulbifera, Dioscorea deltoidea, Tinospora } \\
\text { sinensis, Ficus carica, Ficus lacor, Ficus semicordata, Ficus glaberrima, Ficus nerifolia, } \\
\text { Ficus roxburghii, Artocarpus lacucha, Streblus asper, Bauhinia variegata, Hydnum } \\
\text { repandum, Termitomyces eurhizus, Urtica dioica, Diplazium esculentum, Aesandra } \\
\text { butyracea, Choerospondias axillaris, Ficus auriculata, Nephrolepis auriculata, Picrasma } \\
\text { javanica, Viburnum mullaha,Cinnamomum tamala, Cinnamomum glaucescens, Asparagus } \\
\text { racemosus, Nephrolepis cordifolia, Bambusa nepalensis, and Dendrocalamus strictus }\end{array}$ \\
\hline Medicines & $\begin{array}{l}\text { Justicia adhatoda, Centella asiatica, Emblica officinalis, Rhododendron arboreum, Swertia } \\
\text { chirayita, Myrica esculenta, Rubia manjith, Bergenia ciliate, Taxus baccata, Berberis } \\
\text { aristata, Lycopodium clavutum, Acorus calamus, Aloe vera, Artimisia indica, Asparagus } \\
\text { racemosus, Bauhinia variegata, Brassaiopsis hainla, Paris polyphylla, Rubus ellipticus, } \\
\text { Terminalia bellirica, Terminaia chebula, Vitex negundo, Viscum album, Eurya acuminata, } \\
\text { Zanthoxylum armatum, Rhus javanica, Tribulus terrestris, Amomum aromaticum, Cuscuta } \\
\text { reflexa, Lyonia ovalifolia, Litsea monopetala, Semecarpus anacardium, Sapium insigne, } \\
\text { Woodfordia fruticosa, Osyris wightiana, Aconitum bisma, Centella asiatica, Taxus } \\
\text { wallichiana, Persea duthiei and Dactylorhiza hatagirea }\end{array}$ \\
\hline \multirow[t]{4}{*}{ Raw materials } & $\begin{array}{l}\text { Timber: Schima wallichi, Castanopsis indica, Alnus nepalensis, Pinus roxburghii, Pinus } \\
\text { wallichiana, Abies spectabilis, Daphniphyllum himalense, Castanopsis tribuloides, Quercus } \\
\text { semicarpifolia, Quercus lamelossa, Quercus glauca, Michelia champaca, Rhododendron } \\
\text { arboreum, Juglans regia,Taxus wallichiana and Shorea robusta }\end{array}$ \\
\hline & Bamboo: Arundinaria species, Bambusa nepalensis and Dendrocalamus strictus \\
\hline & Fiber: Girardinia diversifolia, Daphne bholuwa and Edgeworthia gardneri \\
\hline & Construction materials: Sand, gravel and stone \\
\hline \multirow[t]{2}{*}{ Energy sources } & $\begin{array}{l}\text { Fuel-wood: Schima wallichi, Castanopsis indica, Alnus nepalensis, Pinus roxburghii, Pinus } \\
\text { wallichiana, Abies spectabilis, Daphniphyllum himalense, Quercus semicarpifolia, Quercus } \\
\text { lamelossa, Quercus glauca, Rhododendron arboreum, Engelhardia spicata, Lyonia } \\
\text { ovalifolia, Symplocos racemosa, Castanopsis tribuloides, Eurya cerasifolia, Shorea robusta }\end{array}$ \\
\hline & $\begin{array}{l}\text { Charcoal: Schima wallichii and Castanopsis indica, but all species used for fuel-wood and } \\
\text { timber can be used for making charcoal }\end{array}$ \\
\hline Ornamental resources & Rhododendron arboreum, Lycopodium japonicum, Orchid species \\
\hline Water & g water, water for irrigation \\
\hline
\end{tabular}

PPF was found as a source of ornamental plants in the region. The mostly used ornamental plants include; Rhododendron arboreum, Lycopodium clavatum and orchid species (Table 1). A total of 113 species of orchids, including two endemic species, were recorded in PPF (DoF 2012b). The local people used those ornamental plants in decorating their homes, gardens and gates. These ornamental plants were also found to be commonly used by hotel entrepreneurs in decorating their hotels and gardens.

No study was found in protected forests of the country to compare with this study. However, Khanal et al. (2014) observed 12 species of fish, 17 species of fruits, 12 species of timber, 15 species of fodder, and 31 species of medicinal plants in Beeshajari Lake, in the central lowland of Nepal. Large number of species used in PPF compared to Beeshajari Lake is due to the diversity in physiographic zone, local people's dependency on forest for living, and limited number of alternative options. Oort et al. (2015) observed that availability of forest goods, in particular fuel wood, fodder and litter, have decreased because of a strict regulation on forest goods extraction.

In PPF, a total of 20.41 ha $(2.8 \%)$ area was found to be covered by water bodies like streams (Khola), lakes and ponds. Among others, the Harpan Khola, Aandhi Khola and Modi Khola are the major streams originated from the 
PPF. Local communities relied on these water streams and spring sources for drinking water and water for irrigation. The local communities were found to be responsible for protecting, maintaining and managing their water sources used for drinking water and irrigation. They have also formed user committees to regulate drinking water supply and irrigation schemes within the communities. However, the number of households and area of land benefited from irrigation services was very low- nearly 2,000 households and 550 ha respectively (GoN/DoF/UNDP 2014). PPF was also found as a source of water for downstream communities of Kaski, Parbat and Syangja districts. The Harpan Khola, originated from the PPF, was one of the major sources of water for the maintenance of Phewa Lake of Pokhara valley which lies in the downstream of the PPF. The Phewa Lake is the most popular tourist destination of Nepal and one of the lakes of the Ramsar site, the Pokhara Valley Lake cluster.

\section{Regulating services}

Based on experts' opinion and literatures, this study revealed that regulating services offered by PPF include water flow regulation, erosion prevention, water purification, soil fertility maintenance, air quality regulation and climate regulation (Table 2). The PPF is a headwater source for streams such as the Harpan Khola, Aandhi Khola and Modi Khola. Harpan Khola is the major source of water for Phewa Lake in the downstream. The mixed forests, shrub lands and grasslands of PPF control timing and magnitude of runoff and regulate surface-flow and base-flow which ultimately contribute in controlling floods. Mixed forests covered 4,154 ha (72 $\%)$, shrub-lands cover 966 ha (17\%) and grasslands cover 161 ha $(3 \%)$ of the total area of the PPF (DoF 2012b).
Experts and key informants claimed that the Panchase Lake, located at the peak of the Panchase Mountain, and numbers of spring sources within the protected forests are contributing in water recharge in this region. Assessment is needed to quantify the water recharge by the Lake and the spring sources. Over $91 \%$ of the PPF area was covered by vegetation (DoF 2012b) with mixed forests, shrubs and grasslands. The vegetation cover and forest ecosystems act as sponge, intercept rains, and absorb water through root systems. Water is then stored in porous forest soils and debris and then slowly released into surface water and ground water. Through this process, the PPF maintained base-flow and recharged groundwater resulting in continuous flow of streams originated from this area (GoN/DoF/UNDP 2014). PPF helps keeping soil intact and in preventing soil erosion by intercepting rain through forest canopy, slowing down runoff through leaves and natural debris, and stabilizing stream banks through trapping soils by plant roots.

PPF contributes in purifying water through maintaining porous soil by roots of forest, shrub and grass species. Root systems of plants keep soil porous and allow water to filter through various layers of soil before entering groundwater. Although data was not available, the stakeholders believed that through this process, the PPF is also contributing to filter toxic and other substances that pollute water. Forest vegetation improves soil fertility through decomposition of leaf litters, branches, roots and stems. Kalu et al. (2015) has observed that soil quality of the PPF is better than the pasturelands and the cultivated lands in this region. Forest produces humus, regulates nutrient cycling and contributes to soil formation process in the long run.

Table 2. Regulating services provided by Panchase protected forest

\begin{tabular}{|l|l|}
\hline Ecosystem services & \multicolumn{2}{|l|}{} \\
\hline Water flows regulation & $\begin{array}{l}\text { Headwater source for streams/rivers; regulates runoff, surface flow and base flow, control } \\
\text { floods; groundwater recharge }\end{array}$ \\
\hline Erosion prevention & $\begin{array}{l}\text { Soil retention due to vegetation cover and intercepting rain, stabilize stream banks by } \\
\text { sediment retention }\end{array}$ \\
\hline Water purification & Maintenance of soil porosity, filter toxic and other substances \\
\hline $\begin{array}{l}\text { Soil fertility } \\
\text { maintaining }\end{array}$ & $\begin{array}{l}\text { Decomposition of leaf litters, branches, roots and stems; produce humus: regulates nutrient } \\
\text { cycling; soil formation process }\end{array}$ \\
\hline Air quality regulation & Capture dusts and carbon as sink \\
\hline Climate regulation & Carbon sequestration, resilient micro-climate by regulating temperature and precipitation \\
\hline
\end{tabular}

Plants capture carbon dioxide from the atmosphere and release oxygen during photosynthesis process. They also sink dusts from the atmosphere. The PPF, covering vegetation over $91 \%$ of land area and having intact ecosystems, contributed to improve air quality of the nearby areas. As PPF is close to cities such as Pokhara, Kusma, Baglung and Putalibazar, it contributes significantly to improve air quality of those cities. Climate regulation is one of the important services that PPF is providing by sequestrating atmospheric carbon. The forests provide shade, reduce air temperature and create favorable micro-climate in land and water bodies.

\section{Habitat services}

Maintenance of life cycle and genetic resources were found to be the major two habitat services identified 
during the assessment (Table 3). DoF (2012b) has recorded 589 species of plants including 107 species of medicinal herbs, 113 species of orchids $(2$ species endemic to Panchase), 5 species of rhododendrons, 56 species of fungi, 98 species of ferns; 24 species of mammals; and 262 species of birds. Kunwar and Upadhya (2013) have recorded 113 species of orchids in this region. The enriched habitat of PPF is contributing to protect gene pool. It was reported that the PPF was also a habitat for a number of endemic floral species like Ficus neriifolia, Arisaema tortosum, Cissampelos pareira, Berberis aristata, Asparagus racemosus, Reinwardtia indica, Phyllanthus emblica, Cleistocalyx operculatus (GoN/DoF/UNDP 2014).

\section{Cultural and amenity services}

This study revealed that cultural and amenity services of PPF are recreation and tourism, cultural and religious, and cognitive use (Table 4). The PPF offered landscape panorama and a natural heritage site, and thus acts as an attractive destination for domestic and international tourists. Mt. Dhaulagiri, Mt. Manaslu, Mt. Machchhapuchhre, and Mt. Annapurna can be seen from PPF. Bhandari et al. (2018) has estimated that 3,600 tourists visit to PPF every year during autumn (September-November) and spring (March-May). Tourists spend two days in PPF in an average. Being very close to Pokhara city, PPF represents one of the major tourist destinations of Nepal. The Balachaturdasi is one of the major festivals in this region, celebrated on the $14^{\text {th }}$ day of the dark-half of the lunar calendar in the month of Mangsir (late November or early December). Bhandari et al. (2018) has estimated that 25,340 pilgrims visit to PPF every year during Balachaturdasi. Though, most of the pilgrims are Hindus, it also includes other ethnic groups from various parts of the country. Panchase Lake and Panchadham (the temple at the top of Pahchase hill) are the major attractions for the pilgrimage.
In the recent years, PPF is growing as a cognitive site, where students from nearby villages and researchers from different part of the country and across the globe visit to observe and learn various dimensions of nature and people. In 2015, the Central Department of Environmental Science, Tribhuvan University has carried out 22 research works in Panchase Protected Forest including 14 Master's dissertations and eight case studies (CDES-TU 2015).

\section{Beneficiaries of ecosystem services}

The benefits of the ecosystem services provided by PPF range from local, sub-national, national and global levels (Table 5). Paudyal et al. (2017) found that communitybased forestry provides many ecosystem services from local to global beneficiaries. Local communities are mostly benefited from provisioning services (food, raw materials, medicines, energy sources, ornamental resources and water), regulating services (erosion prevention, water purification, air quality regulation, soil fertility maintenance and climate regulation), and cultural and amenity services (recreation and tourism, and cultural and religious). Sub-national level stakeholders are benefited with provisional services (raw materials and water), regulating services (erosion prevention, water purification, air quality regulation and climate regulation), habitat services (life cycle maintenance and genetic resource maintenance), and cultural and amenity services (recreation and tourism, cultural and religious, and cognitive). National level stakeholders mainly benefited with regulating services (climate regulation), habitat services (life cycle maintenance and genetic resource maintenance), and cultural and amenity services (recreation and tourism, cultural and religious, and cognitive). The global level stakeholders are benefited with regulating services (climate regulation), habitat services (genetic resource maintenance), and cultural and amenity services (recreation and tourism, cultural and religious, and cognitive).

Table 3. Habitat services provided by Panchase protected forest

\begin{tabular}{|l|l|}
\hline Ecosystem services \\
\hline $\begin{array}{l}\text { Life cycle } \\
\text { maintenance }\end{array}$ & $\begin{array}{l}107 \text { species of medicinal herbs/plants, 113 species of orchids, 5 species of rhododendrons, 56 } \\
\text { species of fungi, 98 species of ferns; 24 species of mammals \& 262 species of birds (DoF 2012b) }\end{array}$ \\
\hline $\begin{array}{l}\text { Genetic resource } \\
\text { maintenance }\end{array}$ & $\begin{array}{l}\text { Endemic floral species: Ficus neriifolia, Arisaema tortosum, Cissampelos pareira, Berberis } \\
\text { aristata, Asparagus racemosus, Reinwardtia indica, Phyllanthus emblica, Cleistocalyx } \\
\text { operculatus }\end{array}$ \\
\hline
\end{tabular}

Table 4. Cultural and amenity services provided by Panchase protected forest

\begin{tabular}{|l|l|}
\hline \multicolumn{2}{|l|}{ Ecosystem Services } \\
\hline Recreation and tourism & Landscape, natural and cultural heritages \\
\hline Cultural and religious & Panchase Lake, Panchadham, cultural festivals such as Balachaturdasi \\
\hline Cognitive & Educational: students and researchers \\
\hline
\end{tabular}


Table 5. Beneficiaries of ecosystem services provided by PPF

\begin{tabular}{|l|l|l|}
\hline Ecosystem Services & Beneficiaries \\
\hline \multirow{4}{*}{$\begin{array}{l}\text { Provisioning } \\
\text { services }\end{array}$} & Food & Local \\
\cline { 2 - 3 } & Medicines & Local \\
\cline { 2 - 3 } & Raw materials & Local, sub-national \\
\cline { 2 - 3 } & Energy sources & Local \\
\cline { 2 - 3 } & Ornamental resources & Local \\
\cline { 2 - 3 } & Water & Local, sub-national \\
\hline Regulating services & Water flows regulation & Local, sub-national \\
\cline { 2 - 3 } & Erosion prevention & Local, sub-national \\
\cline { 2 - 3 } & Water purification & Local, sub-national \\
\cline { 2 - 3 } & Soil fertility maintaining & Local \\
\cline { 2 - 3 } & Air quality regulation & Local, sub-national \\
\cline { 2 - 3 } & Climate regulation & Local, sub-national, national and global \\
\hline \multirow{5}{*}{ Habitat services } & Life cycle maintenance & Sub-national, national \\
\cline { 2 - 3 } & Genetic resource maintenance & Sub-national, national, and global \\
\hline Cultural and \\
amenity services & Recreation and tourism & Local, sub-national, national, and global \\
\cline { 2 - 3 } & Cultural and religious & Sub-national, national, and global \\
\cline { 2 - 3 } & Cognitive & \\
\hline
\end{tabular}

\section{CONCLUSION}

PPF provided wide range of ecosystem services including provisioning, regulating, habitat, and cultural and amenity services. The provisioning services offered by PPF included food, raw materials, energy, traditional medicines, ornamental resources and water resources. This study concludes that 35 species were used as food, 22 species as raw materials, 17 species as energy sources, 40 species as medicines and 3 species as ornamental resources in Panchase region. Water flow regulation, erosion prevention, water purification, air quality regulation, soil fertility maintenance and climate regulation were the regulating services provided by PPF. Similarly, habitat services offered by PPF included life cycle maintenance for species and genetic resources. Recreation and tourism, cultural and religious, and cognitive values were among the cultural and amenity services provided by PPF. A total number of 3,600 tourists and 25,340 pilgrims visited to PPF every year.

The beneficiaries of the ecosystem services from PPF ranged from people and stakeholders at local, subnational, national and global levels. Most of the provisioning services were distributed at local level; however, raw materials and water resource were distributed at both local and sub-national levels. Similarly, regulating services were distributed at both local and subnational levels. The habitat services were mostly distributed at national and global levels. Cultural and amenity services were distributed at all local, subnational, national and global levels.

\section{ACKNOWLEDGEMENTS}

The authors would like to extend sincere gratitude to the Central Department of Environmental Science, Tribhuvan
University for providing opportunity in carrying this study. Similarly, the authors are thankful to the Department of Forests, Panchase Protected Forest Office, local communities and stakeholders for their support during the study.

\section{REFERENCES}

Baker, J.M. 1998. The effect of community structure on social forestry outcomes: insights from Chota Nagpur, India. Mountain Research and Development 18(1): 51-62.

Baral, S., Basnyat, B., Khanal, R. and Gauli, K. 2016. A total economic valuation of wetland ecosystem services: an evidence from Jagadishpur Ramsar site, Nepal. The Scientific World Journal: ID 2605609.

Bhandari, A.R., Khadka, U.R. and Kanel, K.R. 2018. Economic value of cultural ecosystem services: an assessment from Panchase protected forest of Nepal. International Journal of Science and Research 7(1): 2068-2071.

Cavelier, J. and Gray, I.M. 2012. Payment for ecosystem services. Global environment facility. Washington, DC.

CDES-TU. 2015. Building EbA knowledge in Nepal (Compilation of EbA research studies in Panchase, EbA pilot site.). EbA Tools Validation and Integration for Resilient Mountain Ecosystem in Nepal, Central Department of Environmental Science, Tribhuvan University and Ministry of Forests and Soil Conservation, Kathmandu

Chikanbanjar, R. 2015. Structure and regeneration status of Panchase protected forest. M. Sc. Dissertation, 
Central Department of Environmental Science, Tribhuvan University, Kirtipur, Kathmandu.

CSUWN. 2011. Application of economic valuation toolcase studies from Nepal. Ministry of Forests and Soil Conservation, Kathmandu, Nepal.

Daily, G.C. (Ed). 1997. Natures' services. In: Societal dependence on natural ecosystems. Island Press, Washington, DC.

DFRS. 2015. State of Nepal's forests. Forest Resource Assessment Nepal, Department of Forest Research and Survey, Kathmandu, Nepal.

Dobremez, J.F. 1976. Ecology and biogeography of Nepal. Centre Nationale de la Recherche Scientifique, Paris, France.

DoF. 2012a. Protected forests in Nepal: an introduction. Department of Forests, National Forest Division, Kathmandu.

DoF. 2012b. Panchase protection forest management plan. Department of Forest, Kathmandu.

GoN. 2016. Forest (second amendment) act-2016. In: Nepal Gazette, additional issue 11, part 2 (14 November 2016), Government of Nepal.

GoN/DoF/UNDP. 2014. Ecosystem based adaptation in mountain ecosystems in Nepal.

http://www.np.undp.org/content/dam/nepal/docs/projects/ EbA/UNDP_NP

GoN/MoFSC. 2014. Nepal biodiversity strategy and action plan 2014-2020. Government of Nepal, Ministry of Forests and Soil Conservation, Kathmandu, Nepal.

Kalu, S., Koirala, M., Khadka, U.R. and KC, A. 2015. Soil quality assessment for different land use in the Panchase area of Western Nepal. International Journal of Environmental Protection 5(1): 38-43.

Kanel, K.R. 2015. Cost benefit analysis (CBA) if NTFPs plantations: case of EbA interventions. A report prepared for the EbA Project in Mountain Ecosystems in Nepal Project. Government of Nepal, United Nations Environment Program, United Nations Development Program, International Union for Conservation of Nature, and the German Federal Ministry for the Environment, Nature Conservation, Building and Nuclear Safety.

Khanal, S., Gurung, S.B., Pant, K., Chaudhary, P. and Dangol, D.R. 2014. Ecosystem services and stakeholder analysis in Bishajari lake and associated wetland areas, Chitwan, Nepal. International Journal of Applied Science and Biotechnology 2(4): 563-569.
Kunwar, B.B. and Upadhya, M. 2013. Orchids of Panchase. Institute of Forestry, Tribhuvan University, Pokhara.

MEA. 2005. Millennium ecosystem assessment. In: Ecosystems and Human Wellbeing: Synthesis. Island Press, Washington, DC.

Oort, B. van, Bhatta, L.D., Baral, H.L., Rai, R.K., Dhakal, M., Rucevskae, I. and Adhikari, R. 2015. Assessing community values to support mapping of ecosystem services in the Koshi river basin, Nepal. Ecosystem Services 13: 70-80.

Pant, K.P., Rasul, G., Chhetri, N., Rai, R.K. and Sharma, E. 2012. Value of forest ecosystem services: a quantitative estimation from the Kangchenjunga landscape in eastern Nepal. ICIMOD Working Paper 2012/5. Kathmandu, Nepal.

Paudyal, K., Baral, H.L., Lowell, K. and Keenan, R.J. 2017. Ecosystem services from community-based forestry in Nepal: realizing local and global benefits. Land Use Policy 63: 342-355.

Peh, K.S.H., Thapa, I., Basnyat, M., Balmford, A., Bhattarai, G.P., Bradbury, R.B., Brown, C., Butchart, S.H.M., Dhakal, M., Gurung, H., Hughes, F.M.R., Mulligan, M., Pandeya, B., Stattersfield, A.J., Thomas, D.H.L., Walpole, M. and Merriman, J.C. 2016. Synergies between biodiversity conservation and ecosystem services provision: lesson on integrated ecosystem service valuation from a Himalayan protected area, Nepal. Ecosystem Services 22: 359-369.

Sharma, B., Rausul, G. and Chettri, N. 2015. The economic value of wetland ecosystem services: evidence from the Koshi Tappu Wildlife Reserve, Nepal. Ecosystem Services 12: 84-93

Shrestha, T.K., Aryal, A., Rai, R.K., Lamsal, R.P., Koirala, S., Jnawali, D., Kafle, R., Bhandari, B.P. and Raubenheimer, D. 2014. Balancing wildlife and human needs: the protected forest approach in Nepal. Natural Areas Journal 34(3): 376-380.

Stainton, J.D.A. 1972. Forests of Nepal. John Murray. London.

TEEB. 2010. The economics of ecosystems and biodiversity. The Ecological and Economic Foundation. Earthscan. In: Pushpam Kumar (ed). London and Washington.

Uprety, Y., Poudel, R.C., Shrestha, K.K., Rajbhandary, S., Tiwari, N., Shrestha, U.B. and Asselin, H. 2012. Diversity of use and local knowledge of wild edible plant resources in Nepal. Journaal of Ethnobiology and Ethnomedicine 8(16): 1-15. 